\title{
Innovation as a source of country's global competitiveness growth
}

\author{
Beata Sofrankova ${ }^{1, *}$, Dana Kiselakova $^{1}$, and Veronika Cabinova ${ }^{1}$ \\ ${ }^{1}$ University of Presov in Presov, Faculty of Management, Department of Finance, 08001 Presov, \\ Slovakia
}

\begin{abstract}
In the context of ensuring the long-term prosperity of each country, the more and more emphasis is placed on the mutual comparison of the nation's competitiveness in the European or global area, so every country monitors and supports the development of its global acceptability. The aim of this paper was to analyze the development of Slovakia's competitiveness through the Global Competitiveness Index (GCI) during the period 2006-2016 and to reveal the interrelationships among the GCI indicator and its individual pillars. Of the total 12 pillar scores, a statistically significant correlation with the GCI of Slovakia was confirmed in the case of 7 pillars, whereas the strongest positive relationship was proved for $1^{\text {st }}$ Pillar: Institutions. The level of Slovakia's spending on R\&D belongs to one of the lowest within the EU countries. Over the years 20062015 , the average R\&D intensity fluctuated around $0.68 \%$, whereas in 2015 it reached the value of $1.18 \%$. The top leader in R\&D expenditure per capita within the V4 countries is the Czech Republic followed by Hungary, Poland and Slovakia which in 2015 significantly increased its R\&D spending to the level of $171.7 €$ per capita and ranked $2^{\text {nd }}$ in the V4 countries.
\end{abstract}

Key words: innovation, competitiveness, global, performance

\section{Introduction}

Competitiveness and innovation performance represent two interrelated economic categories that reflect their synergistic effect in different areas of economic and social life [1]. Through innovation, products and services become competitive not only in the domestic but also in the global economy. Nowadays, technology and innovation activities become the main source of economic growth and competitiveness in the local as well as international business environment. This fact is becoming topical and discussed issue, especially in the developed EU countries.

International competitiveness represents one of the alternative performance economic indicators which allows monitoring of all important factors that affect not only economic performance but also many social aspects and social maturity of the country. However,

\footnotetext{
* Corresponding author: beata.sofrankova@unipo.sk
} 
despite all the definitions, in literature there is no clearly defined attitude to the issue of competitiveness as well as its measurement and the way of expression [2].

\subsection{Background in empirical studies and problems}

A market economy is a competitive economy, thus competition is a crucial part of economic activity. A number of economic analyses and research experience show that the national economy development is undoubtedly dependent on the success of domestic producers and their skills to compete effectively in international markets [3].

An inevitable part of assessing the country's economy or economic groupings is to monitor their competitiveness and growth. In general, the most common opinion is that the competitiveness is mainly based on non-tax factors such as stability of the economic environment, enforcement of rights, development of infrastructure, educational level of the population, etc. [4].

The success and growth of each country in today's competitive environment depends not only on national policy, but also on broad public policy, the social qualities of the regions, the creativity and the talents of the country's citizens, and above all by supporting these regional factors [5].

Over the years assessment methodologies relating to global competitiveness have been adjusted to correspond with the current globalization trends in the world economy. Relevant information about several aspects of competitiveness from the perspective of attractiveness of the country for foreign investment and doing business provide a number of reputable international institutions - World Bank (WB), World Economic Forum (WEF), International Institute for Management Development (IMD), The Heritage Foundation (HF), Eurostat and many others. These institutions assess and present internationally comparable results called "competitiveness rankings". They represent a way of multicriteria evaluation through various international aggregated indexes [6].

Many empirical studies are concerned with analysing the global competitiveness of world economies based on the Global Competitiveness Index (GCI). Most authors focus on identifying factors that affect the overall score of the GCI indicator, whether in positive or negative way, and formulate specific solutions to improve the current state of analysed countries. Author as Chudarkova [7] examined the development of national competitiveness of the Visegrad group countries, while the Czech Republic was identified (during the analysed years) as the most competitive economy. The analysis of changes and current position in competitive rankings of this informal group of Central European countries was also performed by Ruzekova, Kastakova and Zatko [8]. However, the results were compared with other multi-criteria indexes World Competitiveness Index (WCI) and Doing Business Index (DBI). To demonstrate differences between evaluations of national competitiveness by applying various approaches, author as Necadova [9] focused on comparing the evaluation of competitiveness based on results in the Global Competitiveness Report with traditional macroeconomic indicators. Confirmation of the positive relationship between the size of EU economies and their achieved level of competitiveness measured by the GCI indicator was the subject of study Necadova [9]. Author as Balcarova [10] studied whether the differences in competitiveness among individual EU economies by using the GCI and WCI indicator decrease or not. Based on results, the convergence was confirmed only in the case of using the GCI indicator.

In recent years, the role of innovation as a tool for increasing the global competitiveness has been intensively discussed in literature. Authors Streimikiene and Fil'a and Kucera [11, 12] in their studies stated that research and development is one of the main drivers of economic growth and creation of modern knowledge based economy that guarantees the efficient use of natural resources and the reduction of negative impact on environment. The 
analysis of relationship and its intensity between innovation and national competitiveness of EU countries tested through econometric analyses was provided by Iosif [13]. She focused on comparison of Innovation Union Scoreboard (IUS) dimensions and their corresponding indicators in relation to the GCI indicator and assessed the effect of innovation's determinants on the international competitiveness of countries. Identification of the usage of information and communication technology (ICT) on international competitiveness of European countries was the subject of study Zoroja [14]. The findings revealed that ICT has the highest impact on the GCI indicator and especially on Efficiency enhancers' sub-index. As reported by Tiruneh and Hekelova [15] the economies with an advanced level of higher education, training and higher level of innovation activities tend to reach a higher level of the GCI indicator compared to countries with lower levels of education and innovation performance.

One of the most significant factors influencing the realization and development of innovation activities is undoubtedly the amount of public investment released to develop country's innovative potential. Author as Necadova [16] examined changes, common and different features in R\&D expenditure in the business sector within the Czech and Slovak Republic and stressed the increasing importance of these financial resources. Authors as Chudarkova [7] discuss about the initial assumptions for starting process of supporting innovation potential and performance in the Czech and Slovak Republic. This process depends on the quality and quantity of human resources and on the intensity of R\&D spending, however, these necessary conditions are not a guarantee of the growth and development of the national and regional innovation capacity of these countries.

Authors as Chudarkova [7] studied the impact of government grants for innovation activities in countries that represent a similar level of economic development - Turkey and Poland. The results confirmed the positive effect of government grants on development in innovation performance of companies in both countries. The analysis of $R \& D$ expenditure impact and development in the Central and Eastern European countries was also provided by Szarowska [17]. She found out that higher government R\&D expenditure by $1 \%$ will increase country's economic growth by $2 \%$. Authors as Czarnitzki [18] also emphasize the importance and positive impact of government support by analyzing the effects of a specific government-sponsored commercial $\mathrm{R} \& \mathrm{D}$ program from various angles. Authors as Aerts and Schmidt [19] analyzed if the public R\&D grants crowd out private R\&D investments in Flanders and Germany. The results of empirical study disproved the hypothesis what was also confirmed by the findings of $[20,21,22,23,24]$ identified as the most significant factors influencing the innovation performance of countries (except for R\&D expenditure) also the number of researchers, number of patents issued, connection of labor market and vocational training system, internationalization of $R \& D$ activities or the degree of appropriate cluster policy implementation.

In the paper we focused on revealing the mutual influence of the individual pillars of the GCI index in Slovakia and finding the strongest and weakest pillars influencing the growth of competitiveness of Slovakia. In the next part of this article, we wanted to find out the relationship between the level of R\&D expenditure in the V4 countries (Slovak Republic, Czech Republic, Hungary and Poland) and the level of competitiveness this countries.

\section{Data and methods}

The aim of this paper was to analyze the development of Slovakia's competitiveness through the Global Competitiveness Index (GCI) during the period 2006-2016 and to reveal the interrelationships among the GCI indicator and its individual pillars. The paper deals with the analysis and comparison of the development of Slovakia's competitiveness based on the GCI indicator during the years 2006-2016 and revealing the significant relationship 
among the overall score of GCI indicator and its individual pillars. In further analyzes we focused on the development of R\&D expenditure in Slovakia and EU countries (28) over the period 2006-2015 as well as their impact on individual pillars of GCI indicator.

In order to achieve stated aims of our study we formulated the following research questions:

RQ1: Is there a statistically significant relationship among the individual pillars of the Slovakia's GCI indicator?

RQ2: Is there a statistically significant relationship among the amount of V4 countries's $R \& D$ expenditure and the score of individual pillars within the overall GCI indicator?

The analyses were prepared on the basis of secondary data drawn from the annual Global Competitiveness Reports and GCI database completed by the World Economic Forum. In the analytical part of presented paper we compared the development of Slovakia's position within the Visegrad group and European Union (28) based on the average scores of the GCI indicator. By correlation analysis we examined the interconnections among the scores of individual pillars and the overall GCI indicator in Slovakia but at first we focused on the development of average GCI pillar scores.

In order to process the secondary data we used the statistical programs STATISTICA and MS EXCEL. From the statistical tools there were the correlation matrix and Kendall's test employed to determine the strength of interdependencies among the selected indicators, which

Based on secondary data gathered from the Global Competitiveness Reports for the years 2006-2016, we focused on the development of Slovakia's GCI indicator compared with its average scores reached in the Visegrad group countries and European Union (28).

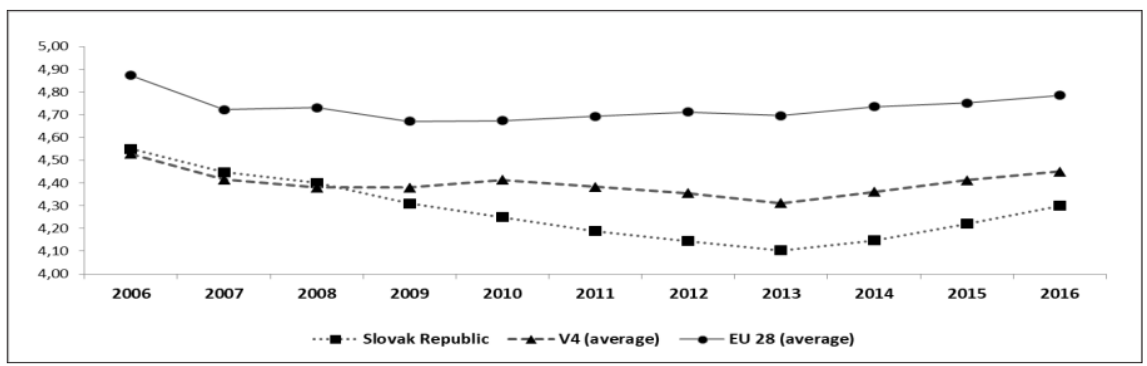

Fig. 1. GCI indicator development analysis of the Slovak Republic over the years 2006-2016

When analyzing the development of the Slovakia's GCI indicator we can notice a negative trend from 2006 to 2013. During the years 2006-2008 Slovakia reached better results of GCI indicator than its average value for all V4 countries. The highest score of Slovakia's GCI indicator (4.55) was achieved in 2006, vice versa, the lowest score was recorded in year 2013 (4.10) and it has increased till 2016 to the level of 4.22. A similar trend was also observed in case of V4 countries. In 2006, the highest GCI average score (V4) was recorded at the level of 4.53 and the lowest value (4.31) was achieved by Visegrad group countries in 2013. In the case of EU countries (28) was the development a bit different, because the worst average results were reached in years 2009 and 2010 (4.67). Despite the fact that since 2010 the GCI indicator (EU) has recorded an increasing trend, the maximum score was achieved in 2006 (4.87) and in 2016 it was only 4.79.

The next part of presented paper was aimed at the development analysis of average GCI pillar scores in Slovakia during the period 2006-2016. The graphic development of values is presented in the following figure. 


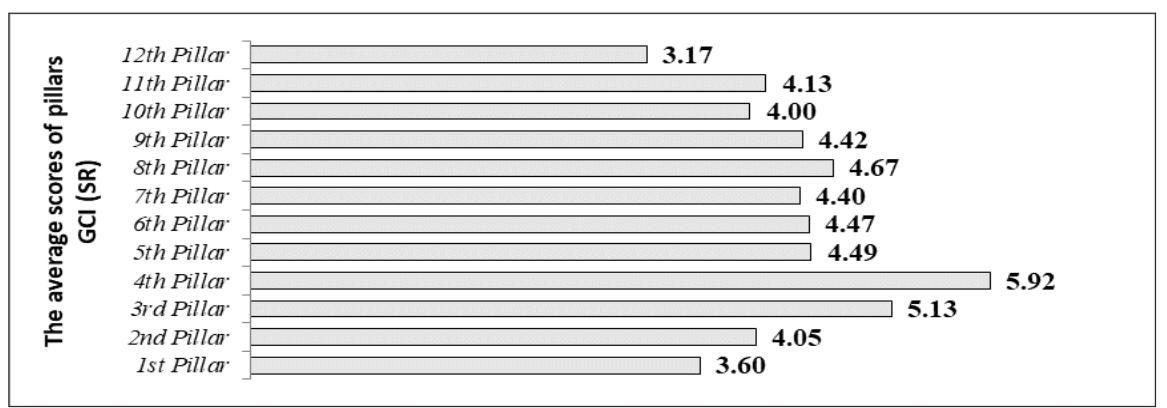

Fig. 2. Development of the average scores of individual GCI (SR) pillars over the years 2006-2016 Source: own processing by data of Global Competitiveness Reports 2006-2016

Based on results of the average scores of individual GCI (SR) pillars it can be concluded that the highest value on average (5.92) was reached within $4^{\text {th }}$ Pillar: Health and primary education, vice versa, the lowest average score (3.17) was recorded in case of $12^{\text {th }}$ Pillar: R\&D Innovation. Insufficient results were achieved by Slovakia also for $1^{\text {st }}$ Pillar: Institutions with its average score of 3.60 .

\section{Results and discussion}

The following analysis is focused on revealing the interrelationships among the overall GCI score and its individual GCI pillars within the Slovak Republic. Significant results of the correlation analysis using the Kendall's test are shown in the next table.

Table 1. Result of the correlation analysis among the GCI (SR) indicator and indexes of 12 pillars

Correlations among scores of Pillar of GCI (SK) Marked correlations are significant at $\mathrm{p}^{*}<0.05(\mathrm{p} * *<0.01)$

\begin{tabular}{|c|c|c|c|c|c|c|c|}
\hline Kendal Tau & $\mathbf{1}^{\text {st }}$ & $\mathbf{2}^{\text {nd }}$ & $\mathbf{3}^{\text {rd }}$ & $\mathbf{6}^{\text {th }}$ & $\mathbf{8}^{\text {th }}$ & $\mathbf{1 1}^{\text {th }}$ & $\mathbf{1 2}^{\text {th }}$ \\
\hline GCI (SK) & $0.7818^{* *}$ & $-0.5138^{*}$ & $0.4630^{*}$ & $0.5872^{*}$ & $0.5636^{*}$ & $0.6853^{* *}$ & $0.5138^{*}$ \\
\hline
\end{tabular}

Source: own processing in STATISTICA

Out of the 12 scores of individual pillars, a statistically significant relationship with the GCI indicator of Slovakia was confirmed for 7 pillars. At the significance level $p<0.05$ we recorded a significant relationship for 5 pillars, while at the significance level $p<0.01$ was significant relationship detected in the case of 2 pillars. Statistically significant relationship was not proved for the following pillar: $4^{\text {th }}$ Pillar: Health and primary education, $5^{\text {th }}$ Pillar: Higher education and training, $7^{\text {th }}$ Pillar: Labor market efficiency, $9^{\text {th }}$ Pillar: Technological readiness and $10^{\text {th }}$ Pillar: Market size.

The highest positive relationship was confirmed in the case of $1^{\text {st }}$ Pillar: Institutions ( $\tau=$ $0.7818)$ followed by $11^{\text {th }}$ Pillar: Business sophistication $(\tau=0.6853)$ and $6^{\text {th }}$ Pillar: Goods market efficiency $(\tau=0.5872)$. The negative relationship was detected only for $2^{\text {nd }}$ Pillar: Infrastructure at the level of $\tau=-0.5138$. For $12^{\text {th }}$ Pillar: R\&D Innovation, the same strong dependency $(\tau=0.5138)$ was revealed as for the $2^{\text {nd }}$ Pillar: Infrastructure, but this dependency was confirmed as positive.

Based on previous analyzes it may be asserted that $1^{\text {st }}$ Pillar: Institutions reached the lowest average score within the evaluation of 12 pillars forming the GCI indicator whereas for this pillar was also confirmed the highest relationship with the GCI indicator. The highest average score within 12 analyzed GCI pillars was reached for $4^{\text {th }}$ Pillar: Health and 
primary education, but the statistically significant relationship between this pillar and the overall GCI score was not proved.

Considering the worst average values attained in the case of $12^{\text {th }}$ Pillar: R\&D Innovation we focused on a more detailed analysis of mentioned pillar and its graphic development presented in the following figure.

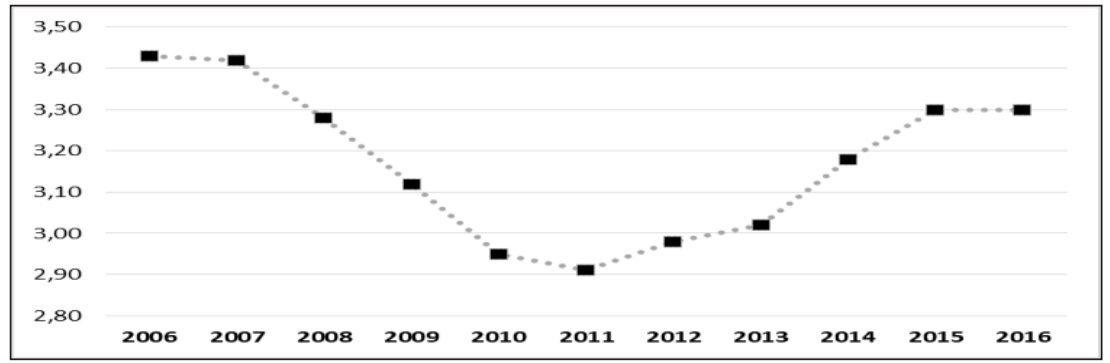

Fig. 3. Development of $12^{\text {th }}$ Pillar: R\&D Innovation over the years 2006-2016

Source: own processing by data of Global Competitiveness Reports 2006-2016

In terms of the development of $12^{\text {th }}$ Pillar: R\&D Innovation we can notice a decreasing trend in years 2006-2011, whereas the highest value of this pillar was noticed in 2006 at the level of 3.43 and lowest value (2.91) was recorded in 2011. Since 2011, the score of $12^{\text {th }}$ Pillar started to increase gradually till 2015 when it reached the level of 3.30 and remained stable also in the following year 2016. The most significant decline $(-5.76 \%)$ was attained in 2010 and the highest increase (+5.03\%) in 2014 .

Following part of presented paper addresses the development of R\&D expenditure within the Slovak Republic and European Union (28).

\subsection{Development analysis of R\&D expenditure in Slovakia}

$R \& D$ expenditure as a percentage of GDP is used as an indicator of an economy's relative degree of investment in generating new knowledge. R\&D intensity of Slovakia belongs to the lowest within the EU countries. The average R\&D expenditure (\% of GDP) moves on the level of $0.68 \%$ during the years 2006-2015. The development of mentioned indicator is shown in the following figure.

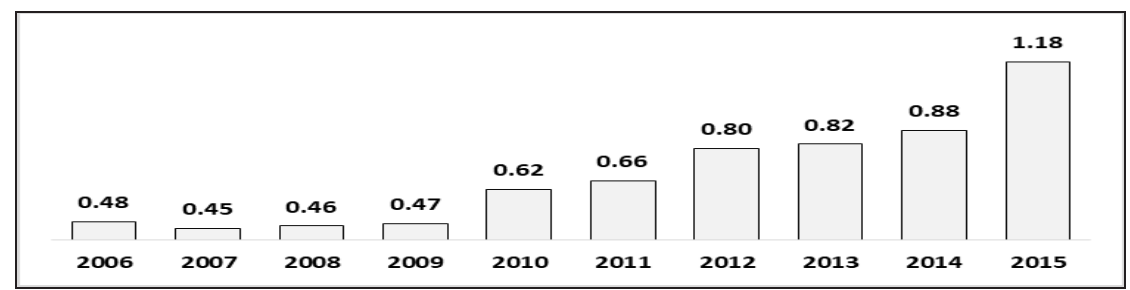

Fig. 4. Development of R\&D expenditures (\% of GDP) in Slovakia over the years 2006-2015 Source: own processing by data of Slovak Office of the Slovak Republic

When assessing the development of the share of R\&D expenditure in Slovakia's GDP, we can notice a gradual increase, whereas the analyzed share fluctuated around $0.5 \%$ from 2006 to 2009, in 2010 and 2011 it increased to the level around $0.6 \%$ and in the following period it was almost around $0.8 \%$. In 2015 , the share of R\&D expenditure increased by more than $146 \%$ compared to the 2006 . 
Although there has been a slight increase of R\&D expenditure (\% of GDP) over the last period, the Slovak Republic is not able to achieve such results as most European countries. However, the level of innovative activity of countries cannot be judged solely in terms of $R \& D$ expenditure. It is important to set up their appropriate amount, structure and interconnection with qualified human resources, innovation strategy and business environment.

Research and development activities can be funded from public resources, private resources, resources from abroad or other resources. It is really interesting to analyze the $R \& D$ expenditure structure in terms of public financial resources and the private ones (see Figure 5).

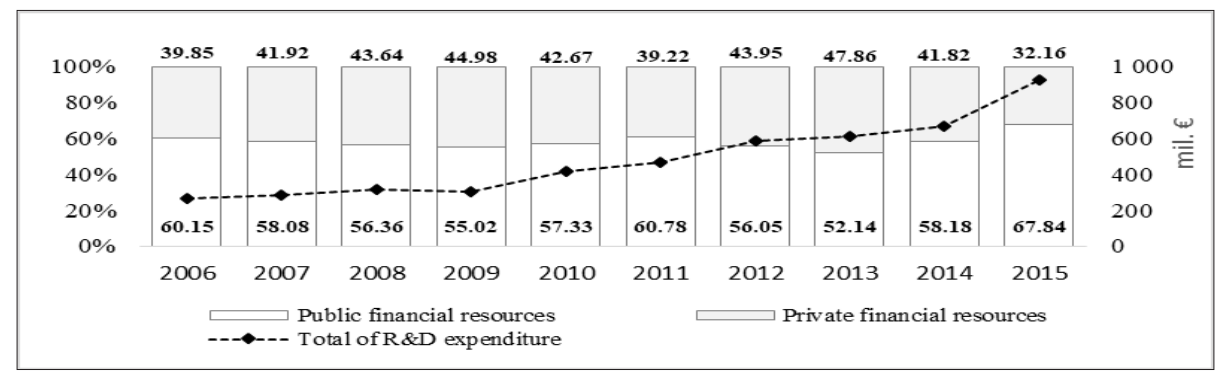

Fig. 5. Structure of R\&D expenditure in the Slovak Republic over the years 2006-2015 Source: own processing by data of Slovak Office of the Slovak Republic

Since 2006, the amount of Slovakia's R\&D expenditure has increased year by year. This positive trend started in 2006 with the total $R \& D$ expenditure of 267.65 million $€$ and till 2015 these financial resources reached its highest year-on-year increase and also the highest value of 927.27 million $€$. The highest year-on-year decrease (- 13.47 million $€$ ) was recorded only in the year 2009. Looking at the structure of $R \& D$ expenditure and its development over the whole analyzed period, it is obvious that public financial resources represented higher share of total resources than the private ones. The average share of public financial resources reached the value of $58.2 \%$ and the remaining share of $41.8 \%$ belonged to private resources. The highest share of public financial resources (67.84\%) was recorded in 2015, vice versa, the lowest share (52.14\%) in 2013 when private resources achieved their maximum values.

In the next part of analysis we dealt with the development comparison of R\&D expenditure per capita during the years 2006-2015 within the Slovak Republic, V4 countries (Slovak Republic, Czech Republic, Hungary, Poland) and European Union countries (28). 


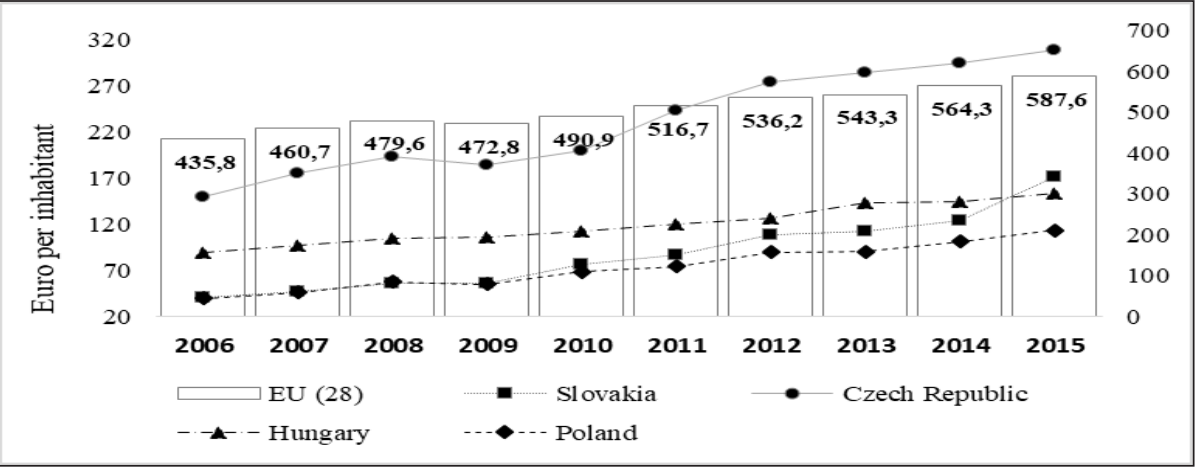

Fig. 6. Structure of R\&D expenditure for the years 2006-2015 (€ per inhabitant)

EU countries (28) invested $435.8 €$ per capita in R\&D activities in 2006. However, gradually ascending trend has led to reaching the level of $587.6 €$ per capita in 2015 that represented an increase of $151.8 €$ per capita in absolute terms $(+34.8 \%)$. Over the analyzed years 2006-2015, the Czech Republic has a dominant position among the Visegrad group countries. It allocated on average $230.78 €$ per capita in R\&D activities, Hungary ranked $2^{\text {nd }}\left(119.87 €\right.$ per capita), the Slovak Republic $3^{\text {rd }}(88.01 €$ per capita) and in the rankings of average $R \& D$ financing Poland recorded the lowest values (73.72 € per capita). Looking at the growing trend in all V4 countries we can notice significantly different and more positive development of R\&D expenditure per capita in the Czech Republic. A slightly different positive trend of mentioned financial resources is detected in the case of Slovakia which in 2006-2009 achieved values almost the same as Poland. In 2015, R\&D spending in Slovakia reached $171.7 €$ per capita representing an increase of $38.4 \%$ compared to 2014. As a result, Slovakia exchanged its position with Hungary and moved up 1 place to reach $2^{\text {nd }}$ position within the V4 countries.

In the following part of the paper, we focused on examining the existence of a statistically significant relationship among the amount of R\&D expenditure and individual pillars of the GCI indicator within the V4 countries.

Table 2. Result of the correlation analysis among the R\&D expenditure and indexes of 12 pillars

\begin{tabular}{|c|c|c|c|c|c|c|c|c|c|c|c|c|}
\hline \multicolumn{13}{|c|}{$\begin{array}{l}\text { Kendall Tau correlations among scores Pillar of GCI (SK, CZ, PL and HU) and R\&D Expenditure (SK, } \\
\text { CZ, PL and HU). Number of observations }=10 \text { for each countries } \\
\text { Marked correlations are significant at } p^{*}<0.05\end{array}$} \\
\hline Pillars & $1^{\text {st }}$ & $2^{\text {nd }}$ & $3^{\text {rd }}$ & $4^{\text {th }}$ & $5^{\text {th }}$ & $6^{\text {th }}$ & $7^{\text {th }}$ & $8^{\text {th }}$ & $9^{\text {th }}$ & $10^{\text {th }}$ & $11^{\text {th }}$ & $12^{\text {th }}$ \\
\hline $\begin{array}{l}\text { R\&D E } \\
\text { (SK) }\end{array}$ & $-0,78 *$ & $0,63^{*}$ & $-0,20$ & 0,09 & $-0,39$ & $-0,58 *$ & $-0,82 *$ & $-0,82 *$ & 0,42 & 0,16 & $-0,45$ & $-0,20$ \\
\hline $\begin{array}{l}\text { R\&D } \\
\text { E(CZ) }\end{array}$ & $-0,24$ & 0,24 & 0,09 & 0,11 & 0,11 & $-0,52 *$ & $-0,45$ & $-0,22$ & $0,78^{*}$ & 0,11 & $-0,45$ & $-0,64 *$ \\
\hline $\begin{array}{l}\text { R\&D E } \\
\text { (HU) }\end{array}$ & $-0,90 *$ & $0,72^{*}$ & $0,56 *$ & $-0,16$ & $-0,02$ & 0,11 & $-0,56^{*}$ & $-0,94 *$ & $0,54 *$ & $-0,23$ & $-0,82$ * & $-0,39$ \\
\hline $\begin{array}{l}\text { R\&D E } \\
\text { (PL) }\end{array}$ & 0,33 & $0,73^{*}$ & 0,00 & 0,18 & $0,60^{*}$ & $0,67 *$ & $-0,43$ & 0,09 & $0,85^{*}$ & 0,80 * & 0,07 & $-0,11$ \\
\hline
\end{tabular}

Source: own processing in STATISTICA

Based on the results of correlation analysis we may assert that the positive relationship among the Poland's R\&D expenditure per capita and individual pillars of the GCI indicator was confirmed in the case of 5 pillars $\left(2^{\text {nd }}, 5^{\text {th }}, 6^{\text {th }}, 9^{\text {th }}\right.$ and $10^{\text {th }}$ Pillar $)$. For the Czech Republic, which is the leader of V4 countries, a statistically significant relationship was noticed for 3 pillars $\left(6^{\text {th }}, 9^{\text {th }}\right.$ and $12^{\text {th }}$ Pillar), however, in case of 2 pillars there was a 
negative dependency revealed. The Slovak Republic demonstrated a statistically significant positive relationship only for $2^{\text {nd }}$ Pillar and the negative dependency was recorded in the case of $1^{\text {st }}, 6^{\text {th }}, 7^{\text {th }}$ and $8^{\text {th }}$ Pillar. According to the revealed results of analyzing the interdependence among the R\&D expenditure and individual pillars of the GCI indicator, a deeper and more detailed analysis as well as a larger range of input data is needed. This topic will be the subject of our further research studies.

\section{Conclusions}

Every year many international organizations, international research institutes or foundations compile multi-criteria evaluations of competitiveness which lead to the compilation of worldwide rankings where countries defend not only their overall position, but also position in selected areas. Those organisations with other multi-criteria evaluation systems of competitiveness provide countries a certain benchmark view on selected aspects and their position in comparison with other countries and analyse macroeconomic performance of the country. Each country follows its range of important economic aspects and features that compares with other states at the global level.

This paper presents the development analysis of Slovakia's competitiveness based on the GCI indicator over the years 2006-2016 as well as the detection of relationships among the individual pillars of the GCI indicator and its overall score. The results revealed that the development of Slovakia's GCI indicator had a decreasing trend till 2013 and in the following years a gradual increase was recorded. In 2016, Slovakia reached the overall GCI score at the value of 4.30. According to the results of average scores we can state that the highest value on average (5.92) was achieved within $4^{\text {th }}$ Pillar: Health and primary education, vice versa, the lowest average score (3.17) was recorded for $12^{\text {th }}$ Pillar: R\&D Innovation. Within the 12 pillars forming the structure of the GCI indicator, the statistically significant relationship with the GCI of Slovakia was revealed in the case of 7 pillars, whereas the strongest positive relationship was confirmed for $1^{\text {st }}$ Pillar: Institutions. The negative dependency $(\tau=-0.5138)$ was detected only for $2^{\text {nd }}$ Pillar: Infrastructure.

In next analyses we also focused on the development of R\&D expenditure in V4 countries during the period 2006-2015 and their influence on individual GCI pillars.

While assessing the development of R\&D expenditure (\% of GDP of Slovakia) over the years 2006-2015, the gradual increase was recorded. The analyzed share fluctuated around $0.5 \%$ in 2006, in the following years it was almost around $0.8 \%$ and in 2015 the share of R\&D expenditure increased by more than 146\% compared to the first analyzed year 2006. The amount of Slovakia's R\&D expenditure recorded a positive increasing trend which started in 2006 at the level of 267.65 million $€$ and till 2015 these financial resources reached the highest value of 927.27 million $€$. Most $R \& D$ expenditure is secured by public financial resources (approximately 60\%) and the remaining share is made up of private ones (about 35-40\%). A substantial part of public resources financing R\&D activities secure only basic research with no linking to the economic performance of the country. Within the V4 countries, the Czech Republic was identified as a leader in R\&D expenditure per capita, followed by Hungary, Poland and Slovakia with one exception in 2015 when R\&D spending in Slovakia attained $171.7 €$ per capita and reached $2^{\text {nd }}$ position.

In conclusion we can say that we found statistically significant relationship among the 7 individual pillars of the Slovakia's GCI indicator. The statistically significant relationship among the amount of V4 countries' R\&D expenditure and the score of individual pillars within the overall GCI indicator were confirmed for each V4 countries (Slovak Republic and Poland -5 pillars, Hungary -7 pillars, Czech Republic -3 pillars) 


\section{References}

1. E. Ivanova, M. Kordos, Competitiveness and innovation performance of regions in Slovak Republic. Marketing and Management of Innovations, 8(1),145-158, (2017)

2. E. Ivanova, M. Kordos, J. Habanik, Microenterprises' entrepreneurs' attitudes to managing financial risks. Actual Problems in Economics, 5(167),39-49, (2015)

3. I. Kravcakova - Vozarova, R. Kotulic, E. Sira, V4 countries' agricultural sector evaluation in terms of competitive advantage. Economic Annals-XXI, 5-6, 60-63 (2015)

4. A. Schultzova, New Challenges in Public Finances 2016. Collection of Scientific Writings on Tax Policy. Bratislava: Ekonóm EU Bratislava (2016)

5. E. Lapinova, M. Varga, B. Sarkanova, Reprodukce lidského kapitálu (RELIK 2016): vzájemné vazby a souvislosti. Mezinárodni vědecká konference. Praha: Vysoká škola ekonomická v Praze, 325-337, (2016)

6. P. Ochotnicky, B. Lajzova, D. Kiselakova, Analysis of macroeconomic factors for the establishment of industrial parks and their effects on regional development: empirical study from Slovakia. Asian Economic and Financial Review, 4(9), 1220-1236 (2011)

7. S. Chudarkova. In: 10th International Scientific Conference on Economic Policy in the European Union Member Countries, 94-104, (2013)

8. V. Ruzekova, V. Kastakova, E. Zatko, Comparison of the V4 Economies According to International Competitiveness Indices and the Basic Pillars of the Knowledge Economy. $3^{\text {rd }}$ International Conference on European Integration (ICEI), 838-848 (2016)

9. M. Necadova, Concepts of Firm and National Competitiveness and Changes in Competitiveness of Visegrad Group Countries. 9th International Days of Statistics and Economics, 1169-1179 (2015)

10. P. Balcarova, Competitiveness of the European Union Countries: Converging or Diverging Tendency? 18th International Conference on Enterprise and the Competitive Environment, 34-45 (2015)

11. D. Streimikiene, Business Infrastructure for Sustainability in Developing Economies. Amfiteatru Economic, 16(37), 965-979 (2014)

12. M. Fila, J. Kucera, Innovation management and corporate sustainability 2015. 3rd International Conference on Innovation Management and Corporate Sustainability (IMACS), 39-51 (2015)

13. A. E. Iosif, Management challenges for Sustainable Development. 8th International Management Conference: Management challenges for Sustainable Development, 670679 (2014)

14. J. Zoroja, Fostering Competitiveness in European Countries with ICT: GCI Agenda. International Journal of Engineering Business Management, 7(18), (2015)

15. M. W. Tiruneh, E. Hekelova, Central Bohemia University International Conference 2016. CBU International Conference on Innovations in Science and Education (CBUIC), 132-141 (2016)

16. M. Necadova. In: 12th International Conference on Hradec Economic Days (HED): Economic Development and Management of Regions, 324-330, (2014)

17. I. Szarowska, European Financial Systems 2017. 14th International Scientific Conference on Economic Policy in the European Union Member Countries, 687-698 (2016) 
18. D. Czarnitzki, C. Lopez-Bento, Value for money? New microeconometric evidence on public R\&D grants in Flanders. Research Policy, 42(1),76-89 (2013)

19. K. Aerts, T. Schmidt, T, Two for the price of one?: Additionally effects of R\&D subsidies: A comparison between Flanders and Germany. Research Policy, 37(5), 806$822(2008)$

20. X. Gonzalez, C. Pazo, Do public subsidies stimulate private R\&D spending? Research Policy, 37(3), 371-389 (2008)

21. B. Svagzdiene, J. Kuklyte, The Analysis of Factors which have Impact for Summary Innovation Index in Germany, Estonia and Lithuania. Transformations in Business \& Economics, 15(2), 784-799 (2016)

22. R. Wiedenhofer, C. Friedl, L. Billy, D. Olejarova, Application of IC-models in a combined public-private sector setting for regional innovation in Slovakia. Journal of Intelectual Capital, 18(3), 588-606 (2017)

23. J. Rahko, Internationalization of corporate R\&D activities and innovation performance. Industrial and Corporate Change, 25(6), 1019-1038 (2016)

24. M. Balog, Development Factors of Cluster Organizations in the Slovak Republic. Journal of Economics, 64(2),148-168 (2016) 
